\title{
Possessor extraction in Indonesian-type languages
}

\author{
Helen Jeoung*
}

\begin{abstract}
This paper examines possessor extraction in three Indonesian-type languages: Indonesian, Javanese and Madurese. I show that possessor extraction patterns are best captured under an analysis in which the possessor undergoes movement from an internal possession structure to the left periphery of the clause; the possessum remains in an A position, while the possessor occurs in an A' position. Possessor movement is subject to general constraints on DP movement in each of these languages, and the voice system determines the ability of the possessor to extract. I discuss implications for the relationship between voice and DP extraction, and conclude that in Indonesian-type languages, voice determines both A and $\mathrm{A}^{\prime}$ movement of any DP moving from within VoiceP.
\end{abstract}

Keywords. external possession; possessor extraction; Indonesian; Javanese; Madurese; voice

1. Introduction. This paper examines the syntax of possessor extraction in three closely related languages. Indonesian, Javanese and Madurese are Indonesian-type languages, a term used in the Austronesian literature to indicate languages of Indonesia that have a similar voice system, often in contrast to Philippine-type languages (Arka 2002, Blust 2013, Cole et al 2008, Himmelman 2002). These three Indonesian-type languages allow external possession as in (1):

Adi yang rumah-nya di-rata-kan kemarin.,

Adi Rel house-Def PV-flat-Appl yesterday

'It was Adi that (his) house was destroyed yesterday.'

In external possession, the possessor occurs outside the nominal constituent with which it has a possession relation. In (1) the possessor Adi occurs external to the DP that contains its possessum, rumah 'house.' The possessor is always followed by a relative morpheme, which is yang in Indonesian (Javanese sing; Madurese se).

I argue that this type of external possession is not derived by base generation of the possessor in its surface position. Rather, a possessor undergoes movement from its possessive DP to a high position at the left periphery of the clause. In the resulting surface configuration, the possessum remains in an A position, and the possessor, an $\mathrm{A}^{\prime}$ position in $\mathrm{CP}$. This movement analysis is supported by the fact that possessor movement is subject to general constraints on DP movement in each of these languages. I refer to this type of external possession as possessor

\footnotetext{
* I thank the following consultants who provided data or discussed judgments with me (alphabetized by first given name): Ekarina Winarto, Iline Megale, Isya Mahfud, M Khoirun Najib, Maimuna, Nadhilah H Semendawai. I also thank David Embick, Julie Legate and Norvin Richards for valuable suggestions. Finally, I am grateful for funding provided by the GAPSA-Provost Award for Interdisciplinary Innovation at the University of Pennsylvania. Author: Helen Jeoung, University of Pennsylvania (jeoungh@sas.upenn.edu).

${ }^{1}$ Data are from my own fieldwork notes unless another source is cited. The Indonesian and Javanese data given in this paper are from the varieties of Indonesian and Javanese spoken in East Java. My Madurese consultants are from Bangkalan and Jember; however, all Madurese data cited in this paper are from the western (Bangkalan) variety.

2 Abbreviations: Appl=applicative; AV=active voice; Def=definite; Excl=exclusive; Incl=inclusive; Int=intransitive; Part=particle; Pol=polite; Poss=possessive; PV=passive voice; Red=reduplication; Rel=relative marker.
} 
extraction (a term also used in Gavruseva 2000 for similar possessor movement).

In the literature on Indonesian-type languages and their respective voice systems, $\mathrm{A}^{\prime}$ extraction of DP arguments has been of interest to many authors. This paper contributes the novel set of data offered by the sub-extraction of the possessor from within DP arguments. I discuss the implications that this analysis has for our understanding of DP extraction, Indonesian-type voice and the relationship between the two.

The paper is organized as follows. In the next section, I outline the syntax and morphology of possession in Indonesian, Javanese and Madurese. In section 3, I show that a movement analysis for external possession correctly captures the data. In section 4, I discuss the consequences of this analysis for Indonesian-type voice systems. Section 5 concludes.

2. Patterns of possessor extraction in Indonesian-type languages. In this section I describe the syntax and morphology of possessor extraction in Indonesian, Javanese and Madurese. Most data are from the colloquial variety of each language, using the familiar register (Indonesian bahasa sehari-hari, Javanese ngoko and Madurese enjha'-iya). ${ }^{3}$ When data are from the polite or high register, it is specifically indicated in the gloss.

2.1. NOMINAL EXTRACTION EMPLOYS A RELATIVE OR PSEUDO-CLEFT. Indonesian, Javanese and Madurese employ a pseudo-cleft or relative construction for DP extraction. Both pseudo-clefts and relatives have the same surface structure (Cole and Hermon 1998, Davies 2000). For example, (1) can have a clefted reading, 'It was Adi whose house was destroyed yesterday.' Alternately, (1) also has a reading in which Adi is modified by a relative, 'Adi whose house was destroyed yesterday.' Nominals modified by relatives may occur embedded in a clause:

Indonesian

Orang yang rumah-nya di-rata-kan kemarin sangat miskin.

person Rel house-Def PV-flat-Appl yesterday very poor

'The person that (his) house was destroyed yesterday, is very poor.'

For both clefts and relatives, the relative morpheme yang must be pronounced. In speech, intonation as well as context disambiguate whether a cleft or relative is intended.

The extracted possessor may either be a lexical possessor or a wh- possessor. Two general strategies are available for forming wh- questions in Indonesian, Javanese and Madurese. Either the wh- phrase may remain in situ, or it may occur as the head of a cleft. ${ }^{4}$ These two strategies are also available for questioning a possessor. First, the wh- possessor may remain in situ:

(3) Indonesian

Siti me-lihat rumah-nya siapa?

Siti AV-see house-Def who

'Whose house did Siti see?'

Alternately, the entire possessive DP may be clefted as in (4):

Indonesian

Rumah siapa yang Siti lihat?

\footnotetext{
${ }^{3}$ The regional and colloquial varieties of Indonesian are less influenced by the prescriptive bias that is often present with Standard Indonesian (Cole et al 2008, Sneddon 2006).

${ }^{4}$ In Indonesian, wh in situ is not available when a question is embedded under a matrix $\mathrm{V}$ that does not select a wh complement (Saddy 1991); in that case partial or long distance wh-movement is obligatory. Madurese does not have long-distance movement (Davies 2003).
} 
house who Rel Siti see

'Whose house did Siti see?'

Both wh- in situ and clefted wh-phrases are interpreted as matrix interrogative clauses (Saddy 1991). Note that subjects must be specific or definite in these languages (Davies 2010, Sato 2008, Sneddon et al 2012). Since a wh- word is nonspecific, a clefted wh-phrase is the only strategy available for subject questions. A third question strategy is also possible with possessor extraction:

(5) Siapa yang Siti lihat rumah-nya?

who Rel Siti see house-Def

'Who was it that Siti saw (his) house?'

In (5) the wh- possessor siapa moves out from its possessive DP and is the head of the cleft. The possessum rumahnya remains in situ, low in the clause.

2.2. THE STRUCTURE OF PSEUDO-CLEFTS AND RELATIVES. Recent literature on clefts in Austronesian languages (Aldridge 2013, Massam 2003, Paul 2001, Pearson 2001) has shown that (4) and (5) are a type of pseudo-cleft, with the structure shown below:

(6)

Pseudo-cleft structure

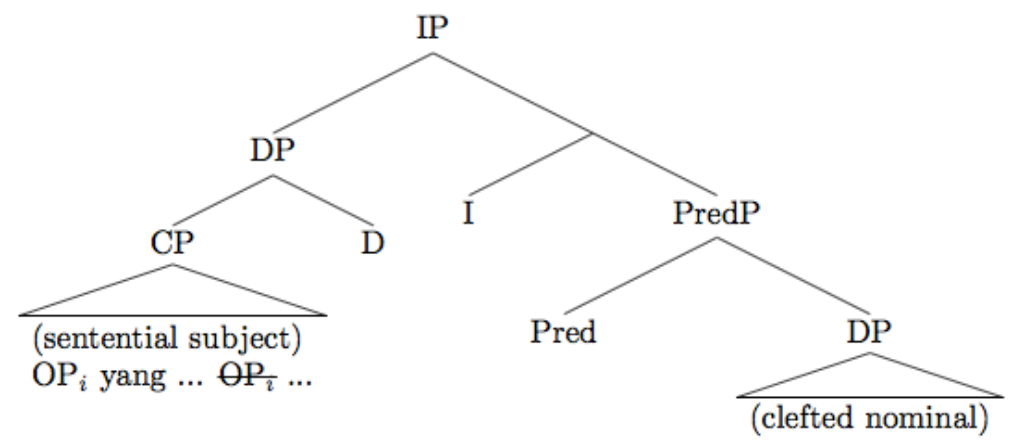

A pseudo-cleft is composed of a headless relative clause that is the matrix subject, and the clefted nominal is generated as the predicate of the matrix clause. ${ }^{5}$ For the sentence in (1), the headless relative yang rumahnya diratakan kemarin is generated as subject; and Adi is generated as the predicate. Movement obtains via a null operator within the relative clause. The headless relative is always introduced by the morpheme yang; I assume that movement of the null operator over $\mathrm{C}$ requires that $\mathrm{C}$ is overt, i.e. spelled out as yang (and I assume the same movement over $\mathrm{C}^{0}$ in a relative clause also requires spell-out as yang.) This $\mathrm{CP}$ is embedded under a DP; the resulting interpretation of the headless relative is akin to 'the one that...'

The surface word order of the pseudo-cleft is derived by raising the clefted nominal from its base-generated position to SpecCP. Under this analysis, it is not surprising that in these languages, the clefted nominal can either occur in its base-generated position $(7 \mathrm{a}, 8 \mathrm{a}, 9 \mathrm{a})$, or sentence initially $(7 \mathrm{~b}, 8 \mathrm{~b}, 9 \mathrm{~b})$ :

(7) Indonesian

a. Yang ber-warna biru buku-nya David. Rel Int-color color book-Def David

\footnotetext{
${ }^{5}$ Note that copula is null in these languages.
} 
'(The one) that is blue, is David's book.'

b. Buku-nya David yang ber-warna biru. book-Def David Rel Int-color blue 'It is David's book that is blue.'

(8)

Javanese

a. Sing seneng mangan permen arek iku lo.

Rel happy eat candy child that Part

'(The one) that likes to eat candy, is that child.'

b. Arek iku sing seneng mangan permen.

child that Rel happy eat candy

'It is that child that likes to eat candy.'

Madurese

a. Se e-bacah bi' ale' apah?

Rel PV-read by younger.sib what

'(The one) that was read by little brother, was what?'

b. Apah se e-bacah bi' ale'?

what Rel PV-read by younger.sib

'What was read by little brother?'

Furthermore, Saddy (1991) observes that in Indonesian, the declarative complementizer bahwa can co-occur with yang when partial wh- movement occurs: ${ }^{6}$

(10) Indonesian (Saddy 1991, example 12)

Bill tahu bahwa siapa yang Tom cintai.

Bill know $\mathrm{C} \quad$ who Rel Tom love

'Bill knows who Tom loves.'

Similar structures with two complementizers are also possible in Javanese and Madurese. I take the declarative complementizer bahwa to be located in the CP projection associated with [force], and yang in a lower CP projection where [focus] attracts focused elements (following Rizzi 1997 inter alia). I will assume that all possessive DPs and possessors (both lexical and wh-) land in the lower CP (Focus) projection. The structure of relatives is identical to that of the CP headless relative in a pseudo cleft, and similarly, movement is via a null operator that lands in SpecCP, requiring yang to be overt. This $\mathrm{CP}$ modifies the head noun by adjunction.

For simplicity, in this paper I refer to these pseudo-cleft structures as "clefts," and I refer to the predicational DP as a "clefted DP." I also abstract away from the difference between movement which obtains via a null operator and the movement of constituents. For example, I refer to operator movement from subject position as "possessor sub-extraction from subject," etc.

\subsection{Core DATA: Possessor EXTRACTION In IndONESIAN, JAVANESE AND MADURESE. Below I} outline the syntactic positions from which a possessor may move out of its possessive DP in Indonesian-type languages. For each language I show whether sub-extraction is possible from a grammatical subject, from a VP-internal object, and from an adjunct. ${ }^{7}$

\footnotetext{
${ }^{6}$ This structure with two overt complementizers is judged to be rather formal in Indonesian.

${ }^{7}$ Either a lexical possessor or wh-possessor is shown to extract, but the choice of one or the other in the following examples is arbitrary; they pattern the same with regard to A' movement. Likewise, the glosses indicate either a
} 
I begin with colloquial Indonesian. Both internal and external possession are illustrated below; (a) examples are the internal possession constructions, and (b) examples are external possession constructions. First, an internal possessor embedded in a DP that is in the canonical preverbal position of grammatical subject (11a) may also be an external possessor (11b):

(11) Indonesian - External possessor from grammatical subject

a. Rumah Adi di-rata-kan kemarin. house Adi PV-flat-Appl yesterday 'Adi's house was destroyed yesterday.'

b. Adi yang rumah-nya di-rata-kan kemarin. Adi Rel house-Def PV-flat-Appl yesterday 'It was Adi that (his) house was destroyed yesterday.'

The internal possessor embedded in the possessive DP in object position (12a) may also occur as external possessor $(12 b)$ :

(12) Indonesian - External possessor from object

a. Tono cubit pipi-nya anak itu.

Tono $\varnothing$-pinch cheek-Def child that

'Tono pinched the child's cheek.'

b. Aku kenal anak yang Tono cubit pipi-nya.

1 sg know child Rel Tono $\varnothing$-pinch cheek-Def

'I know the child that Tono pinched (his) cheek.'

Note that external possession is only possible in active clauses when the verb is "bare," i.e. bears a null voice morpheme.

External possession is not possible in Indonesian, however, when the possessive DP is embedded in an adjunct:

(13) Indonesian - No external possessor from adjunct

a. Aku mau rapat di sekolah-nya Fatima. 1sg want meet at school-Def Fatima 'I will go to a meeting at Fatima's school.'

b. *Siapa yang aku mau rapat di sekolah-nya?

Fatima Rel 1sg want meet at school-Def

'Who was it that I will go to a meeting at her school?'

Turning to colloquial Javanese, we find that possessor extraction has the same pattern as Indonesian. Possessors may be extracted from the grammatical subject (14) or from the object (15) when the verb is in the "bare" form.

(14) Javanese - External possessor from grammatical subject

a. Buku-ne Rini di-woco adik.

Book-Def Rini PV-read younger.sib

'Rini's book was read by little brother.'

b. Sopo sing buku-ne di-woco adik?

Who Rel book-Def PV-read young.sblng

relative or clefted reading, but both readings are usually possible; the gloss given for each example does not reflect which reading is more salient. 
'Whose book was read by little brother?'

(15) Javanese - External possessor from object

a. Kene woco buku-ne penulis iku. 1pl.Incl $\varnothing$-read book-Def author that

'We read that author book.'

b. penulis iku sing kene woco buku-ne author that Rel 1pl.Incl $\emptyset$-read book-Def 'the author that we read (his) book'

And similarly to Indonesian, possessor extraction is impossible from adjuncts (16):

(16) Javanese - No external possessor from adjunct

a. Aku maeng ketemu wong asli kampung-e mama-ku. $1 \mathrm{sg}$ before meet person origin neighborhood-Def mother-1sg 'I met someone [originally from my mother's neighborhood].'

b. *Mama-ku sing aku maeng ketemu wong asli kampung-e. mother-1sg Rel $1 \mathrm{sg}$ before meet person origin neighborhood-Def 'It was my mother that I met someone [originally from her neighborhood].'

Possessor extraction in familiar Madurese contrasts with the pattern in Indonesian and Javanese. Whereas Indonesian and Javanese possessors can move from both grammatical subject and object, in Madurese, the possessor may only move from the grammatical subject (17), but may not be extracted from the object (18) or from an adjunct (19).

(17) Madurese - External possessor from grammatical subject

a. Buku-nah Tono e-bacah ale'. book-Def Tono PV-read younger.sibling 'Tono's book was read by little brother.'

b. Sapah se buku-nah e-bacah ale'? who Rel book-Def PV-read younger.sibling 'Who was it that (his) book was read by little brother?'

(18) Madurese - No external possessor from object

a. Engko' bacah/m-acah buku-nah sapah? $1 \mathrm{sg} \quad \emptyset$-read/AV-read book-Def who 'Whose book am I reading?'

b. *Sapah se engko' bacah/m-acah buku-nah? who Rel 1sg $\emptyset$-read/AV-read book-Def 'Who is it that I am reading (his) book?'

(19) Madurese - No possessor extraction from adjunct

a. Engko' mole darih romah-nah Fatima. $1 \mathrm{sg}$ go.home from house-Def Fatima 'I went home from Fatima's house.'

b. *Sapah se engko' mole darih romah-nah? who Rel 1sg go.home from house-Def 'Who was it that I went home from her house?'

(18) provides the main point of contrast between Madurese on one hand and Indonesian and Javanese on the other. Extraction and sub-extraction from object position is ungrammatical in Madurese, whether or not the verb is prefixed with the active voice morpheme. This type of 
extraction is grammatical in Indonesian and Javanese, provided the verb is "bare." The extraction patterns discussed thus far are summarized in Table 1.

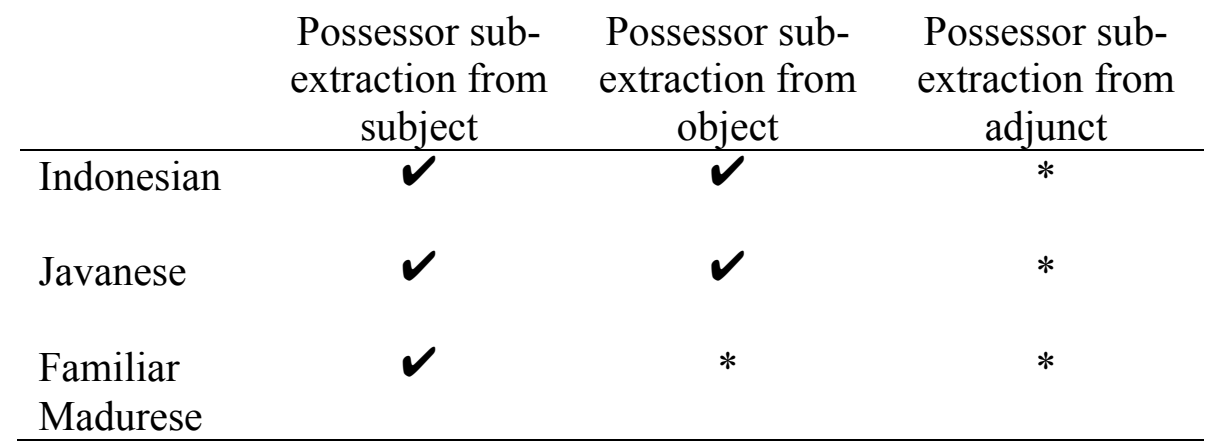

Table 1: Possessor sub-extraction across the three languages

In section 3 I discuss how the patterns in Table 1 are determined by the voice system of these Indonesian-type languages, and in fact, are expected in light of the relationship between voice and DP movement in each language.

2.4. THE STRUCTURE OF THE POSSESSIVE DP. In this section I first discuss the structure of possessive DPs, which is strikingly similar across these Indonesian-type languages. Then in the following section (2.5) I discuss the mechanism by which possessors extract from their DPs.

Possessive DPs in Indonesian, Javanese and Madurese have a similar surface order: the possessum occurs with a definite suffix, followed by the possessor:

(20) Indonesian

a. kantor dia / kantor(-nya) dia

office $3 \mathrm{sg}$ office-Def $3 \mathrm{sg}$ 'her office'

b. tangan-ku / tangan(*-nya) aku hand-1sg hand-Def $1 \mathrm{sg}$ 'my hand'

c. uang orang kaya/ uang(-nya) orang kaya money person rich money-Def person rich 'rich person's money'

(21) Javanese $^{8}$

a. buku(-ne) Titin book-Def Titin

'Titin's book'

b. omah(-e) Rini

house-Def Rini

'Rini's house'

(22) Madurese ${ }^{9}$

a. ata'-eng roma

\footnotetext{
${ }^{8}$ The definite morpheme in Javanese is -ne after vowels and -e after consonants; but in the variety represented here, speakers variably use -e after vowels as well.

${ }^{9}$ The definite morpheme in Madurese is realized as -eng following a glottal stop, - nah following a vowel and -Cah elsewhere where $\mathrm{C}$ is geminate with the preceding consonant (Stevens 1968, Davies 2010).
} 


\section{roof-Def house \\ 'house's roof' \\ b. obu'-eng Siti \\ hair-Def Siti \\ 'Siti's hair'}

Note that in these Indonesian-type languages, one possessive structure is used for both animate and inanimate possessors, and the possession relation can be either alienable or inalienable. Additionally, the possessor may be a pronoun, pronominal clitic, name or full DP.

In Indonesian and Javanese, an overt definite suffix does not occur with a first- or secondperson pronoun (20b), but the definite suffix may co-occur with the free third person pronoun dia (usually for emphasis or contrast). In standard (prescriptive) Indonesian, the definite morpheme does not usually occur between the possessum and the possessor, unless an additional layer of definiteness is intended. ${ }^{10}$ In colloquial Indonesian and Javanese however, there is variability and some speakers prefer to pronounce $-n y a /-(n) e$ in $(20 \mathrm{a}, 20 \mathrm{c}, 21 \mathrm{a}, 21 \mathrm{~b})$. In contrast, -nah is obligatorily pronounced in Madurese internal possession structures (22).

Whether D is pronounced or not, a possessive DP counts as definite (i.e. satisfies the definite/specific requirement for subjects) if the possessor is definite or specific. Thus (20c) and (22a) may not be the subject of a clause because they have indefinite possessors and are thus indefinite DPs; the other possessive DPs in (20-22) are definite. ${ }^{11}$

I assume the following structure for possessive DPs in Indonesian, Javanese and Madurese:

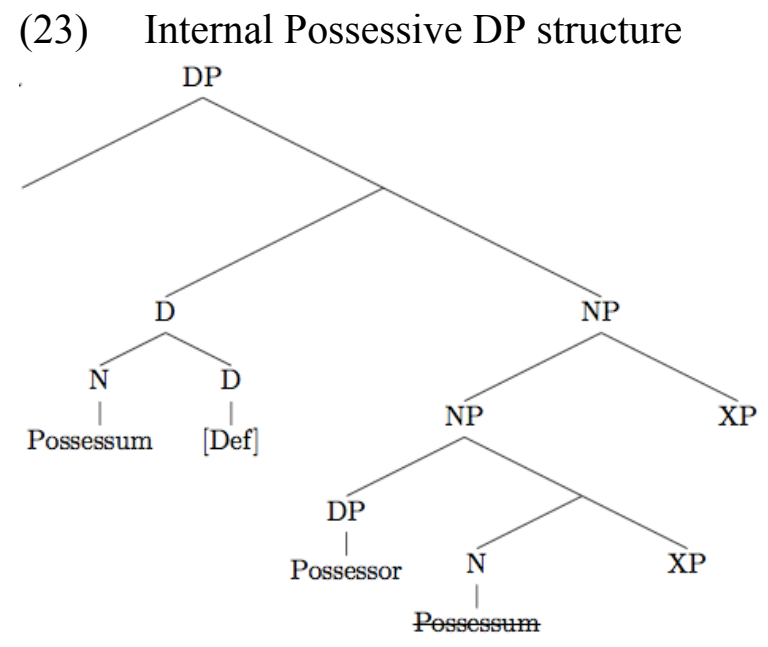

The possessum undergoes head movement to adjoin D; D is spelled out as a suffix on the possessum. I assume that the possessor is generated in the specifier of NP as an argument of the possessum, where it is assigned a thematic Possessor role and checked for Case.

Given the structure in (23), PP adjuncts must occur to the right of the possessor in all three languages (because of space considerations, the examples below are from one language only):

(24) Javanese
a. murid-e
Siti [teko' Jakarta]

\footnotetext{
${ }^{10}$ Roughly speaking, in (20a), the difference between 'her office' and 'the office of hers.' See Winarto (2016) on double-marking of definiteness.

11 (20c) and (22a) are possible subjects only if they are interpreted as generic bare nouns.
} 

student-Def Siti from Jakarta
'Siti's student from Jakarta'
b. *murid-e [teko' Jakarta] Siti
c. *murid [teko' Jakarta] -e Siti

In the case of adjectives modifying the head noun as in the Madurese example in (25a), the possessor may not intervene between them (25b). Rather, in all three languages, the adjective must be embedded inside a relative with an overt relative morpheme (25c):

(25) Madurese
a. mored (se) tengghi
student Rel tall
'tall student'
b. *mored tengghi -nah Siti
c. mored-dhah Siti *(se) tengghi student-Def Siti Rel tall 'Siti's student that is tall'

For nominal complements, they must be embedded in a PP if separated from the head noun:

(26) Indonesian
a. buku cerita anak
book story child
'book of children's stories'
b. *buku Siti cerita anak
book Siti story child
'Siti's book of children's stories'
c. buku Siti tentang/dengan cerita anak
buku Siti about with story child
'Siti's book of children's stories'

Thus when an adjectival modifier is separated from its head noun, the modifier must be introduced with yang or P. This holds true even for multiple adjectives in non-possessive DPs: across all three languages, stacking more than one adjective is not possible (27a). The second adjective must be embedded in a relative $(27 \mathrm{~b})$, or the adjectives must be coordinated within a relative clause $(27 \mathrm{c})$ :

(27) Madurese
a. *mored (se) penter tengghi
student Rel smart tall
'smart, tall student'
b. mored penter *(se) tengghi
student smart Rel tall
'smart student that is tall'
c. mored *(se) penter bi' tengghi
student Rel smart and tall
'student who is smart and tall'

2.5. THE STATUS OF -D: POSSESSIVE PRONOUN OR DEFINITE MARKER? When the possessor has been extracted, the possessum obligatorily occurs with a -D suffix. Is -nya/-ne/-nah a possessive 
pronominal element, or a definite morpheme? In the latter case, it would be a resumptive pronoun, taking the place of the lower copy of the moved possessor. However, I show that in cases of possessor extraction, the -D suffixed to the possessum must be only definite marking.

I begin with Madurese. In (28), -nah is not bound by a c-commanding quantifier; the antecedent of 'books' may either be 'each student,' or another referent:

Madurese

Sabban mored ny-aba ku-buku-nah neng meja. each student AV-place Red-book-Def at table

'Each student 1 placed his $1 /$ her $_{2} /$ the book on the table.'

This is unexpected if $-n a h$ is a pronominal element, as we would expect the quantifier sabban 'each' to force binding of - nah, which it c-commands. Additionally, if 'books' has already been mentioned in the discourse, it is felicitious to use kubukunah without a possessive interpretation. This is expected if -nah is a definite marker that obligatorily occurs in possessive DPs; if 'books' has not been mentioned in the discourse (and anaphoric definiteness is not possible), the possessive interpretation is available. Thus, when the possessor is not overt in a Madurese possessive DP, definiteness marking on the nominal signals that it may be a possessum.

The Indonesian morpheme - nya has at least three functions: possessive pronominal clitic, definite marker and 3 person (Patient) pronominal clitic (Saddy 1991, Sneddon et al 2012). Javanese -(n)e has at least two functions: possessive pronominal clitic and definite marker. I propose that when the possessor moves out of its internal possession structure, i.e. in all cases of possessor extraction, -nya/-(n)e must be a definite marker rather than a pronoun, as is the case in Madurese. The presence of $-n y a /-(n) e$ is expected if the definite marker is optionally pronounced with internal possession, but obligatorily overt with external possession. Movement of the possessor over the definite marker requires that the morpheme be pronounced.

2.6. EXTRACTION THROUGH SPECDP. I propose the possessor must move through the specifier of DP in order to be available for extraction (see Szabolcsi 1992 for similar movement in Hungarian). An EPP feature on matrix D must target DPs only; this is consistent with other DPonly extraction facts (adjuncts cannot be clefted or be relativized in these languages). Thus EPP in these languages is always associated with D, i.e. an EPP-D feature. The possessor DP raises to the specifier of the matrix DP to check features on D, and from SpecDP it may then be extracted from the DP:

Possessor extraction via SpecDP

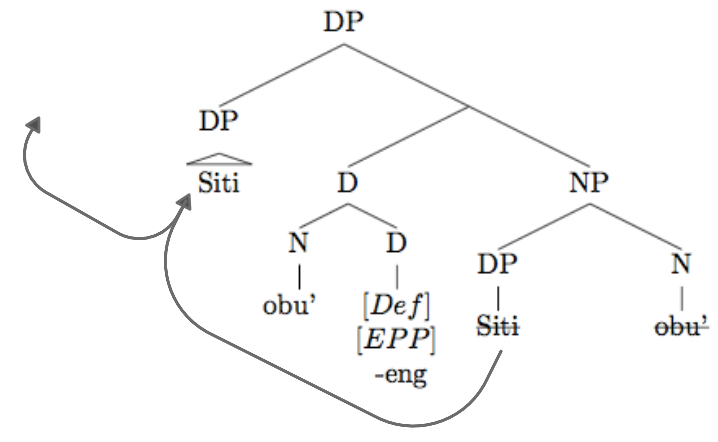

Recall that for clefts and relatives, either the subject of the clause, or the possessor of the subject, may be extracted. Thus either the maximal projection (the entire possessive DP) or its specifier (the possessor DP) can be targeted for extraction; in (29) matrix DP and SpecDP must be 
equidistant for further movement operations.

A question that follows is whether possessors can be pronounced in the SpecDP position; in other words, whether the DP can remain in SpecDP without further extraction. It appears that possessors do not appear immediately prenominally, which needs explanation. If possessors covertly raise to SpecDP, they may not be pronounced because the feature motivating the movement is a weak feature (in the sense of Richards 2001); the lower copy must be pronounced if the possessor does not move out of the DP. Thus possessors pass through SpecDP, but must continue to another position via cyclic movement in order to be pronounced in a higher position.

3. A movement analysis for possessor extraction. In section 2 , I outlined the syntactic configurations in which possessor extraction is licit in Indonesian, Javanese and Madurese, but did not provide a principled explanation for those patterns. In this section I show that the availability of possessor extraction falls out naturally from independent principles determined by the voice system of each language.

In Indonesian-type languages, voice is morphologically marked on verbs. ${ }^{12}$ I assume that voice morphology instantiates the functional head Voice ${ }^{0}$, which is part of the extended verbal structure of the clause:

(30) Clause structure in Indonesian-type languages

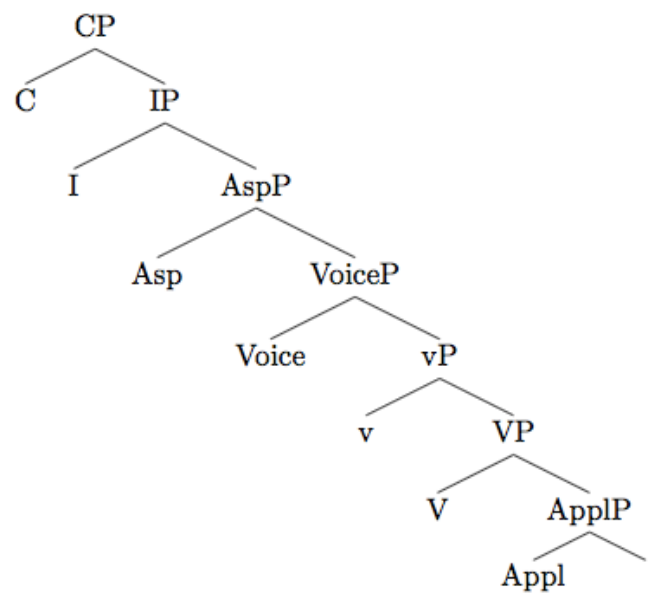

Head movement within the verbal domain results in the following linear order: [Voice- $-\mathrm{V}-\mathrm{V}-$ Appl]. Voice, v and Appl occur as affixes on the verb root. The external argument of the verb is merged in SpecVoiceP, where it receives it thematic role, and in active voice, raises above AspectP to the specifier of IP. ${ }^{13}$

In Indonesian-type languages, subject DPs can extract via A' movement. This includes derived subjects, e.g. a raised Theme in a passive or object voice clause. We have already seen examples of subject extraction, e.g. (4). In contrast, object extraction is only possible in Indonesian and Javanese under the condition previously mentioned: the voice morphology on the verb must be null. Thus the extraction in (31) and (32) is ungrammatical if the active prefix occurs on the verb:

\footnotetext{
${ }^{12}$ Active voice morphology is sometimes optional in Indonesian, but word order is indicative of voice when the active prefix is omitted (Cole et al 2008). Active voice morphology is obligatory in Javanese and Madurese (Davies 2010, Sato 2008).

${ }^{13}$ Following Legate 2014. Alternately, Cole et al 2008 assume that external arguments are merged in Spec,vP.
} 
(31) Indonesian

Apa yang Daud sudah baca / *mem-baca?

what Rel Daud Perf 0-read AV-read

'What did David read?'

(32) Javanese

Opo sing Daud kate woco / *m-oco?

what Rel Daud will 0-read AV-read

'What will David read?'

In familiar Madurese, however, objects may not extract, even if the verb is "bare":

(33) Madurese

*Buku jiyah se Daud la bacah / m-acah.

book that Rel Daud Perf 0-read AV-read

'It is that book that David read.'

Thus the contrast between Indonesian/Javanese on one hand, and Madurese on the other, is reflected not only in the number of voices, but also in the DP extraction patterns.

The possessor extraction data previously summarized Table 2 is expanded below to include general extraction patterns in each language:

\begin{tabular}{|c|c|c|c|c|c|c|}
\hline & $\begin{array}{l}\text { Extraction } \\
\text { of } \\
\text { grammatical } \\
\text { subject }\end{array}$ & $\begin{array}{l}\text { Possessor sub- } \\
\text { extraction } \\
\text { from } \\
\text { subject }\end{array}$ & $\begin{array}{c}\text { Extraction } \\
\text { of } \\
\text { object }\end{array}$ & $\begin{array}{l}\text { Possessor sub- } \\
\text { extraction } \\
\text { from } \\
\text { object }\end{array}$ & $\begin{array}{c}\text { Extraction } \\
\text { of } \\
\text { adjunct }\end{array}$ & $\begin{array}{c}\text { Possessor } \\
\text { sub-extraction } \\
\text { from adjunct }\end{array}$ \\
\hline Indonesian & $\checkmark$ & $V$ & $\checkmark$ & $\checkmark$ & $V$ & * \\
\hline Javanese & $\checkmark$ & $\gamma$ & $\checkmark$ & $\checkmark$ & $\checkmark$ & $*$ \\
\hline $\begin{array}{l}\text { Familiar } \\
\text { Madurese }\end{array}$ & $\checkmark$ & $\gamma$ & $*$ & * & $\checkmark$ & * \\
\hline
\end{tabular}

Table 2: Extraction patterns for DP arguments and Possessors

We observe in Table 2 that possessor extraction displays a pattern identical to that of DP argument extraction in Indonesian, Javanese and Madurese. In other words, so long as a DP may be extracted from a particular position in the clause, the possessor embedded within the DP may also be extracted.

The question that follows is why a DP may not be sub-extracted from an adjunct, e.g. a PP adjunct which may appear in a high (clause-initial) position in all three languages. Crosslinguistically, it is well-known that adjuncts are as strong islands, so it is not surprising that subextraction from adjuncts is impossible. Additionally, it is not clear whether adjuncts actually move from low positions to high surface positions in these languages. In other Austronesian languages, AP and PP can be clefted or relativized. However, in Indonesian, Javanese and Madurese, AP and PP adjuncts cannot appear with yang/sing/se, so it is unclear whether they undergo A' movement, or whether they are base-generated in high positions.

To briefly summarize the present discussion: I have shown that a movement analysis for external possessors straightforwardly captures the data in Indonesian-type languages. Possessors may escape the DP by moving through its specifier; from this position the matrix DP and the DP in its specifier are equidistant for further movement. The syntactic positions from which 
possessors may or may not extract are completely determined by the voice of the clause; if the matrix DP may extract, so too its possessor, and vice versa. A base-generation account of external possession fails to capture these patterns.

4. Discussion and implications. Analyses of DP extraction in Indonesian-types languages have been implemented in different ways. For example, Aldridge (2008) proposes a phase-based analysis, in which a strong EPP feature on $v$ is absent in active voice; briefly speaking, the object cannot be raised to the edge of the vP phase and thus cannot extract. In another type of approach, Cole et al (2008) propose that Indonesian has voice "agreement." The voice morphology on the verb must reflect the thematic or Case position from which a DP has moved. The active prefix indicates that the external argument has been extracted; null morphology indicates that an object has been extracted. A morphological constraint (specific to certain varieties of Indonesian) prevents any DP from moving through the edge of the phase that hosts voice morphology, if the morphosyntactic properties of Voice ${ }^{0}$ do not agree with it. Despite the differences in these two approaches, they both assume that movement through the edge of $v \mathrm{P}$ (or VoiceP) depends on the functional head that controls the voice properties of the clause; and DPs must move through this phase edge in order to extract.

Returning to the structure in (30), note that both external and internal arguments are merged in the extended verbal domain within VoiceP. I assume VoiceP is the relevant domain for successive cyclic movement (i.e. a phase). Movement of DPs must pass through the edge of VoiceP as well as the edge of CP (alternately, CP and the highest verbal projection posited for a particular language) (Rackowski 2002, Rackowski and Richards 2005, van Urk and Richards, to appear).

Possessor extraction brings some new insight to analyses of Indonesian-type voice systems. First, possessor extraction demonstrates that the voice of the clause does not only determine the configuration of verbal arguments, but the movement of DPs in general: the possessor is not an argument of the verb, but rather a possessive argument of N. Thus, if the voice system regulates movement of possessor DPs, then voice is concerned with all DPs that shift out of VoiceP. In other words, possessor extraction allows us to separate two distinct issues: 1) morphological voice marking as a reflex of DP movement (showing the position from which the DP has moved out of VoiceP), and 2) voice marking that reflects the position of its arguments.

The first view appears to be correct. Recall that sub-extraction of the possessor from object position is grammatical in Indonesian and Javanese; and the null voice prefix is required just as when the object extracts. The object of the verb has not shifted, since the head $\mathrm{N}$, the possessum remains in its merged position. Yet extraction of a non-argument, the possessor, requires that the voice morphology reflect that a DP has been extracted (or perhaps only moved to the edge of VoiceP). If the possessor is sub-extracted from the external argument, the distinction is irrelevant from the perspective of voice. When the posseessor is extracted, the subject DP has already moved out of VoiceP and the voice morphology reflects the first instance of movement.

In connection with this idea, in Indonesian-type languages, both A and A' movement appear to be dependent on the voice system in Indonesian-type languages. Evidence that A' movement must also be subject to Voice ${ }^{0}$ has been mentioned already, in connection with null voice marking when objects are extracted in Indonesian and Javanese. ${ }^{14}$ This morphological requirement suggests that Voice $^{0}$ must be involved in $\mathrm{A}^{\prime}$ movement as well. The active Voice

\footnotetext{
${ }^{14}$ Familiar Madurese does not allow object extraction at all, and also does not allow bare verb forms (Jeoung 2016). This further strengthens the case that the morphology that instantiates Voice ${ }^{0}$ is correlated with $\mathrm{A}^{\prime}$ movement.
} 
head does not allow the object DP to undergo any movement (whether A or A'); the null Voice ${ }^{0}$ head permits such movement. (Under standard assumptions, passive VoiceP is assumed not to be a phase and so movement through the phase edge is not required.)

Furthermore, in many Austronesian languages, including familiar Madurese and several colloquial varieties of Indonesian and Malay (Cole et al 2008), a "subject-only" restriction is said to apply. The claim is that only DPs which are first made the grammatical subject can be extracted via $\mathrm{A}^{\prime}$ movement. This particular way of thinking about the restriction on $\mathrm{A}^{\prime}$ movement is descriptive, but it incorrectly suggests that it is the (high) structural position of subjects (i.e. SpecIP) which allows extraction to occur; C cannot find a DP that is too low in the clause. However, the ability of Indonesian and Javanese possessors to extract from object position suggests that the subject-only formulation of the restriction is inaccurate. I suggest that the impossibility of A' movement is determined within VoiceP, even for languages which do not allow objects to extract. It is the ability to move to the edge of VoiceP that determines whether a DP is available for A' movement, as suggested by Aldridge (2008) and Cole et al (2008) for Indonesian; as well as Rackowski (2002) and Rackowski and Richards (2005) for Tagalog.

5. Conclusions. This paper began with a presentation of possessor extraction data in three Indonesian-type languages. The data show that possessor extraction patterns are best captured under an analysis in which the possessor undergoes focus movement from an internal possession structure to $\mathrm{CP}$ so that the possessum remains in an A position, and the possessor, an $\mathrm{A}^{\prime}$ position. Possessor movement is subject to general constraints on DP movement in each of these languages, and the voice system determines the ability of the possessor to extract in a predictable way. Possessor extraction also provides a window into voice systems in Indonesian-type languages. I discussed the implications of possessor extraction for analyses of Indonesian-type voice and its relationship to DP extraction. The data support the idea that voice in these languages not only determines A movement of its arguments, but both A and A' movement of any DP within VoiceP.

\section{References}

Aldridge, Edith. 2008. Phase-based account of extraction in Indonesian. Lingua 118(10).14401469. http://faculty.washington.edu/aldr/pdf/ISML.pdf.

Aldridge, Edith. 2013. Wh-clefts and verb-initial word order in Austronesian languages. In Cleft Structures. 71-96. Philadelphia: John Benjamins.

Arka I Wayan. 2002. Voice systems in the Austronesian languages of Nusantara: Typology, symmetricality and undergoer orientation. http://hdl.handle.net/1885/41058.

Blust, Robert. 2013. The Austronesian Languages. Asia-Pacific Linguistics.

Cole, Peter and Gabriella Hermon. 1998. The typology of WH-movement: WH-questions in Malay. Syntax 1(3):221-258.

Cole, Peter, Gabriella Hermon and Yanti. 2008. Voice in Malay/Indonesian. Lingua 118:15001553. http://www.sciencedirect.com/science/article/pii/S0024384107001490.

Davies, William D. 2000. The syntax of the Madurese cleft. Manuscript, University of Iowa. http://semantics.uchicago.edu/kennedy/classes/w07/readings/davies03.pdf.

Davies, William D. 2003. Extreme locality in Madurese WH-questions. Syntax 6(3):237-259. http://semantics.uchicago.edu/kennedy/classes/w07/readings/davies03.pdf.

Davies, William D. 2010. A Grammar of Madurese. DeGruyter Mouton.

Davies, William D. and Craig A. Dresser. 2005. The structure of Javanese and Madurese Determiner Phrases. Proceedings of AFLA 12, the Twelfth Meeting of the Austronesian Formal 
Linguistics Association.

http://citeseerx.ist.psu.edu/viewdoc/download?doi=10.1.1.592.1931\&rep=rep1\&type=pdf.

Himmelmann, Nikolaus, 2002. Voice in western Austronesian: An update. The History and Typology of Western Austronesian Voice, F. Wouk and M. Ross, eds. Pacific Linguistics, Canberra, 7-16.

Jeoung, Helen. 2016. Voice and register differences in Madurese. Proceedings of the $22^{\text {nd }}$ Annual Meeting of the Austronesian Formal Linguistics Association. https://digitalcollections.anu.edu.au/handle/1885/101155.

Legate, Julie Anne. 2014. Voice and v: Lessons from Acehnese. MIT Press.

Paul, Ileana. 2001. Concealed pseudo-clefts. Lingua 111(10):707-727. http://www.sciencedirect.com/science/article/pii/S0024384100000449.

Pearson, Matthew. 2001. The Clause Structure of Malagasy: A Minimalist Approach. PhD dissertation, UCLA.

Rackowski, Andrew and Norvin Richards. 2005. Phase edge and extraction: A Tagalog case study. Linguistic Inquiry 36(4):565-599.

http://web.mit.edu/norvin/www/papers/Tagalogextraction.pdf.

Richards, Norvin. 2001. Movement in Language: Interactions and Architectures. OUP.

Rizzi, Luigi. 1997. The fine structure of the left periphery. In Elements of grammar, 281-337. Springer.

Saddy, Douglas. 1991. WH scope mechanisms in Bahasa Indonesia. In More papers on WH move- ment, L. Cheng and H. Demirdache, eds., 183-218. MIT Working Papers in Linguistics 15, MIT.

Sato, Yosuke. 2008. Minimalist Interfaces: Selected Issues in Indonesian and Javanese. Ph.D dissertation, Univeristy of Arizona. http://ling.auf.net/lingbuzz/000669/current.pdf.

Szabolcsi, Anna. 1992. The Noun Phrase. PhD dissertation, UCLA. http://philpapers.org/archive/SZATNP.pdf. 